\title{
A EFICIÊNCIA COMO OBJETO DE DESENVOLVIMENTO
}

THE EFFICIENCY AS AN OBJECT OF DEVELOPMENT

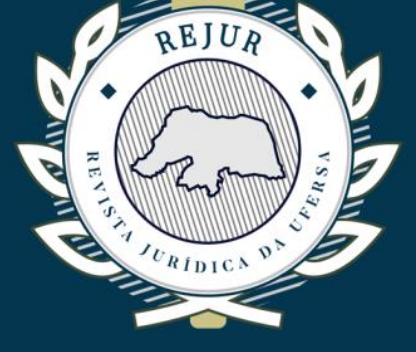

\section{Patrícia Borba Vilar Guimarães* | Thiago Garcia**}

RESUMO

Este estudo tem como objetivo demonstrar a íntima relação entre o princípio constitucional da eficiência e o objetivo constitucional de desenvolvimento. Demonstra-se que apesar das críticas de que como princípio não é aplicável ao sistema jurídico, em virtude das teorias apresentadas sob o enfoque utilitarista ou de seu valor econômico, a eficiência revela-se um poderoso instrumento de desenvolvimento à medida que os conceitos econômicos são utilizados para fazer uma releitura do sistema jurídico, como orientadores, não como doutrinadores, de tal maneira que a persecução da eficiência contribua sobremaneira para o aumento das liberdades que sob a perspectiva de Amartya Sen são fins e meios para o desenvolvimento.

Palavras-chave: Eficiência. Desenvolvimento. Recursos públicos.

\section{ABSTRACT}

This study aims to establish a relationship between the constitutional principle of efficiency and the constitutional objective of development. There are criticisms that efficiency as a principle is not applicable to the legal system because theories are presented focused on the utilitarian approach and emphasize economic value. But, can be high-level development tools, when economic concepts are used to reread the legal system. Concepts are visible as guides and not as doctrinators. In this way, the search for efficiency contributes to the increase of freedoms, purposes and means for development, from the perspective of Amartya Sen.

Keywords: Efficiency. Development. Public resources.

\footnotetext{
* Doutora em Recursos Naturais pela Universidade Federal de Campina Grande (UFCG). Mestre em Direito pela Universidade Federal do Rio Grande do Norte (UFRN). Advogada. Professora da UFRN. patriciaborb@gmail.com

** Graduado em Direito pela UFRN. thiago_garcia97@hotmail.com
} 


\section{SUMÁRIO}

\section{INTRODUÇÃO; 1 CONCEITO DE EFICIÊNCIA; 2 CONCEITO DE DESENVOLVIMENTO; 3 EFICIÊNCIA COMO INSTRUMENTO DE DESENVOLVIMENTO; 4 A EFICIÊNCIA E O DIREITO: UM EXEMPLO; CONCLUSÕES; REFERÊNCIAS BIBLIOGRÁFICAS.}

\section{- INTRODUÇÃO}

Constantemente, os noticiários relatam casos de desvio de recursos públicos que fragilizam as contas públicas e findam por obstar o desenvolvimento. Em meados dos anos 1990, a eficiência foi adicionada aos princípios constitucionais expressos, o que deveria influenciar de maneira substancial a Administração Pública. Entende-se que, diante da grave crise fiscal enfrentada pelos vários entes da federação, a utilização eficiente dos recursos públicos merece maior atenção.

A Constituição Federal relaciona entre os objetivos fundamentais da República a garantia do desenvolvimento nacional (art. 3ำ, inc. II). No caput do artigo 37 encontram-se os princípios norteadores da Administração Pública, modificado pela emenda constitucional no 19 de 1998, que formalmente inseriu o princípio da eficiência como norte fundamental dos atos administrativos.

A ideia de desenvolvimento ligada exclusivamente ao crescimento econômico já fora objeto de intensa discussão. Amartya Sen, por exemplo, apresentou como desenvolvida aquela sociedade que garanta liberdades aos seus cidadãos, não apenas riqueza.

A má gestão do dinheiro público pode gerar consequências devastadoras e, às vezes, irreversíveis para a sociedade, pois retira dos administrados a oportunidade de obterem melhores condições (qualidade) de vida, restringido, portanto, suas liberdades e direitos.

Este estudo objetiva demonstrar a relação existente entre a eficiência e o objetivo republicano de desenvolvimento. Pretende-se apontar que apesar das críticas de que a eficiência como princípio não é aplicável ao sistema jurídico - em virtude das teorias apresentadas sob o enfoque utilitarista ou de seu valor econômico, a eficiência revela-se um poderoso instrumento de desenvolvimento à medida que os conceitos econômicos são utilizados para fazer uma releitura do sistema jurídico - como orientadores, não como doutrinadores, de tal maneira que a persecução da eficiência contribui sobremaneira para o aumento das liberdades, que sob a perspectiva de Amartya Sen são fins e meios para o desenvolvimento.

A metodologia empregada nesta pesquisa é a revisão de literatura com aplicação do método dedutivo analisado sob a perspectiva de uma problemática da realidade. Os materiais de pesquisa utilizados são obras de doutrinadores administrativistas e constitucionalistas, além de textos científicos de economistas e estudiosos do direito ao desenvolvimento.

Esta pesquisa se divide em três sessões. Inicialmente busca-se contextualizar o leitor acerca da conceituação dos termos eficiência e desenvolvimento. Em seguida, demonstra-se 
a relação entre ambos. Por fim faz-se um breve apanhado da análise econômica do direito atrelada ao princípio da eficiência como instrumento de prevenção de ilícitos.

\section{CONCEITUANDO EFICIÊNCIA}

Os princípios são comparados a uma estrutura que mantém firme uma edificação. Servem como "vigas mestras" ou "apoio lógico ao edifício científico". São pressupostos pontos referenciais para a ciência jurídica"

Entende-se que os princípios são as estruturas, alicerces sob as quais, como normas reguladoras, as leis se sustentam. Ao mesmo tempo em que atuam como espírito ou fundamento das normas, os princípios mostram-se critérios de compreensão e inteligência do sistema jurídico ${ }^{2}$.

Os princípios norteadores da administração pública foram listados no art. 37, caput, da Constituição da República de 1988. Por esse dispositivo, a administração pública de qualquer dos poderes deveria obedecer a estes princípios: legalidade, impessoalidade, moralidade e publicidade. Posteriormente, foi incorporado ao texto constitucional através da Emenda Constitucional no 19 de 1998: o princípio da eficiência.

Apesar de não ser um princípio expresso, o dever de agir com eficiência não era uma novidade. O Decreto-Lei no 200/1967 já previa, por exemplo, que a supervisão ministerial tinha como objetivo a eficiência administrativa. Também, a própria redação original do texto constitucional destacava que os três poderes deveriam manter sistema de controle interno com a finalidade de comprovar a legalidade e avaliar os resultados, quanto à eficácia e eficiência, da gestão orçamentária, financeira e patrimonial nos órgãos e entidades da administração federal, bem como da aplicação de recursos públicos por entidades de direito privado (art. 74, inc. II). Ademais, ainda dispunha que a lei disciplinaria a organização e o funcionamento dos órgãos responsáveis pela segurança pública, de maneira a garantir a eficiência de suas atividades (art. 144, $\S 70$ ). Sendo assim, qual a razão para a emenda constitucional?

A Exposição de Motivos Interministerial - EMI no 49/1995 expõe que o Estado brasileiro estava, àquela altura, inserido em um contexto de crise econômica que já se estendia por 15 (quinze) anos. Para aquele governo, a reforma administrativa que invariavelmente implicaria em mudanças constitucionais seria necessária para o devido equacionamento da crise fiscal. O objetivo era assimilar novos conceitos que conduzissem a ação estatal em direção à eficiência e à qualidade dos serviços prestados.

Os resultados esperados demonstram certa congruência com a conceituação do termo, à frente apresentada. Dentre os resultados esperados, estava à incorporação da eficiência na administração pública, em que o Estado, usando os recursos disponíveis, deveria estar apto a gerar mais benefícios. As medidas propostas visavam "transformar a

\footnotetext{
${ }^{1}$ REALE, Miguel. Filosofia do Direito. São Paulo: Saraiva, 19a edição, 2002, p. 59-61.

${ }^{2}$ BANDEIRA DE MELLO, Celso Antônio. Curso de Direito Administrativo. São Paulo: Malheiros, 32a edição, 2015, p. 54.
} 
administração pública brasileira em poderoso instrumento do desenvolvimento econômico e social" 3 .

Os recursos públicos são escassos e finitos. A eficiência parte do conceito econômico de conseguir maiores benefícios com a aplicação dos mesmos recursos, os mesmos benefícios com a aplicação de menos recursos, ou ambos ${ }^{4}$.

A eficiência não é propriamente um conceito jurídico, mas econômico. É o emprego de racionalidade a medição e aplicação dos custos e utilidades que satisfazem as necessidades públicas ${ }^{5}$.

Apesar de não haver sobreposição entre os princípios, sob pena de isso trazer insegurança jurídica ${ }^{6}$, o professor Vladimir da Rocha França defende não ser concebível a administração pública não ser investida da "obrigação de ser diligente e criteriosa na busca e efetivação do interesse público", tendo, ademais, ainda maior relevância "quando se está diante da discricionariedade administrativa"7.

A partir da segunda metade do século XX, o pensamento jurídico influenciado pelas ideias de Ronald $\mathrm{H}$. Coase, mais tarde incrementadas pelas de Richard Posner, passaram a ser disseminadas internacionalmente num movimento que ficou conhecido como Law and Economics ou Análise Econômica do Direito (AED) ${ }^{8}$.

Inicialmente, Posner defendeu o método da AED a fim de analisar as normas de maneira a promover a eficiência, maximizando o bem-estar social. Segundo esse modelo os recursos econômicos deveriam ser usados de maneira que o confronto entre a satisfação e custo, alcançasse o nível máximo, através da maximização entre custos e vantagens ${ }^{9}$.

Os professores Cooter \& Ulen apresentaram uma síntese da relação entre economia e direito na obra Direito \& Economia. Para eles, a eficiência é sempre relevante para a definição de políticas públicas, pois é melhor atingi-las a um custo menor do que a um custo mais alto ${ }^{10}$.

Destacam que para os economistas, a eficiência se dá quando uma destas duas condições é atingida: não é possível atingir o mesmo resultado a um custo menor ou não é possível alcançar melhores resultados com o mesmo custo ${ }^{11}$.

Todavia, o conceito acima é associado ao conceito de eficiência econômica. 0 modelo de eficiência social, apresentado através da eficiência ou ótimo de Pareto, consiste na

\footnotetext{
${ }^{3}$ Cf. EMI no 49/1995.

${ }^{4}$ PEDRAJA, F.; SALINAS, J. Es posible medir la eficiencia de los servicios públicos? ECONOMISTAS - COLEGIO DE MADRID, Madrid, $n^{\circ} 105$, p. 86-93, jul 2005, p. 86-93.

${ }^{5}$ SILVA, José Afonso da. Curso de direito constitucional positivo, São Paulo: Malheiros, 2005, p. 671

6 DI PIETRO, Maria Sylvia Zanella. Direito administrativo. 32. ed. - Rio de Janeiro: Forense, 2019, p. 245.

${ }^{7}$ FRANÇA, Vladimir da Rocha. Eficiência administrativa na Constituição Federal. Revista de Direito Administrativo, Rio de Janeiro, v. 220, p. 165-177, abr. 2000. ISSN 2238-5177. Disponível em: <http://bibliotecadigital.fgv.br/ojs/index.php/rda/article/view/47532>. Acesso em: 04 Jun. 2019.

${ }^{8}$ TABAK, Benjamin Miranda. A Análise Econômica do Direito: Proposições Legislativas e Políticas Públicas. Revista de Informação Legislativa, v. 52, p. 321-345, 2015, p. 323.

${ }^{9}$ FONSECA, João Bosco Leopoldino da. Direito econômico. 9. ed. rev., atual., e ampl. - Rio de Janeiro: Forense, 2017, p. 33, 34.

${ }^{10}$ COOTER, R.; ULEN, T.. Direito \& Economia. 5 ed. Tradução Luis M. Sander e Francisco Araújo da Costa. Porto Alegre: Bookman, 2010, p. 26.

11 Ibid., p. 38.
} 
maximização do bem-estar social à medida que se tornar impossível aumentar o bem-estar de um indivíduo sem que isso implique em piorar o bem-estar de outro ${ }^{12}$.

Mas, a aplicação prática da eficiência de Pareto não é algo fácil. Nem sempre é possível melhorar a situação de uma parte sem que isso prejudique a outra. De maneira que "geralmente haverá um ganhador e um perdedor, de forma que o julgamento resultará no aumento do bem-estar de uma parte e na redução do bem-estar da outra" ${ }^{13}$.

Outra teoria, a de Kaldor-Hicks, mede a eficiência a partir de uma visão global e não interna as partes. Caso o benefício total seja maior que o custo total inicial, resultando numa evidente melhoria global, a medida se tornou eficiente. O problema é que a medida pode ser eficiente mesmo que o bem-estar de uma parte tenha sido atingido negativamente, pois a medida teria gerado melhora no bem-estar global ${ }^{14}$.

Por isso, há aqueles que entendem esses critérios de aferição da eficiência como contrapostos aos argumentos de natureza ética e social ${ }^{15}$. Entretanto, é valido retomar o entendimento de que o objetivo empregado aos conceitos econômicos é fazer uma releitura do sistema jurídico, valendo-se de regras e princípios econômicos como orientadores, não como doutrinadores ${ }^{16}$.

Baseado nesses ideais econômicos é que juristas apresentam o princípio da eficiência econômica como orientador da administração pública a fim de se conseguir os melhores resultados ao custo de utilização da menor quantidade possível dos recursos escassos.

Há uma subdivisão ao princípio da eficiência, uma relacionada à ação do agente público e outra relacionada à organização e estrutura da administração pública, porém, requerendo que ambos desempenhem as suas funções de maneira a atingir os melhores resultados possíveis ${ }^{17}$.

Essa obrigação do administrador não é vinculada apenas ao princípio da moralidade, mas a eficiência se pressupõe à medida que o dever demonstra ser o de "alcançar a solução que seja ótima ao atendimento das finalidades públicas". Assim, não bastando à observação da possibilidade ou legalidade, mas importando que seja "a melhor solução" ${ }^{18}$.

A eficiência - associada à administração pública - estabelece um método de ação que conduz a resultados céleres e satisfatórios, o que, infelizmente, não é próprio da realidade brasileira, salvo raras exceções ${ }^{19}$.

\footnotetext{
12 NIED, Paulo Sérgio. O conceito de eficiência econômica e a ruptura do contrato de sociedade. In: XXI Encontro Nacional do CONPEDI, 2012, Uberlândia. Anais do XXI Encontro Nacional do CONPEDI. Florianópolis: Fundação Boiteux, 2012, p. 4297-4314.

${ }^{13}$ Ibid.

${ }^{14} \mathrm{lbid}$.

${ }^{15}$ SEN, Amartya Kumar. Desenvolvimento como liberdade. 4ạ reimpressão, São Paulo: Companhia das Letras, 2010, p. 318-321.

${ }^{16}$ COOTER, R.; ULEN, T.. Direito \& Economia. 5 ed. Tradução Luis M. Sander e Francisco Araújo da Costa. Porto Alegre: Bookman, 2010, p. 25-33.

17 DI PIETRO, Maria Sylvia Zanella. Direito administrativo. 32a. ed. - Rio de Janeiro: Forense, 2019, p. 243-244.

18 HÄRGER, Marcelo. Reflexões Iniciais sobre o Princípio da Eficiência, Revista de Direito Administrativo, Rio de Janeiro: Renovar, n. 217, p.151-161, dez. 1999.

${ }^{19}$ MEDAUAR, Odete. Direito Administrativo moderno. Belo Horizonte: Fórum, 21a edição, 2018, p. 127.
} 
Nesse sentido, o princípio da eficiência reúne três ideias centrais: prestabilidade, presteza e economicidade. A prestabilidade está relacionada ao atendimento público; a presteza à celeridade; e a economicidade a satisfação "alcançada do modo menos oneroso possível". Assim, "para satisfazer o princípio constitucional da eficiência, a Administração Pública deve atender o cidadão na exata medida da necessidade deste e com agilidade, mediante adequada organização interna e ótimo aproveitamento dos recursos disponíveis"20. A eficiência se traduz na "exigência de promoção satisfatória dos fins atribuídos à administração pública" ${ }^{21}$.

Detalhe que às vezes passa despercebido ou não é relacionado por alguns doutrinadores quanto à eficiência é que esta impõe a administração pública a busca pela qualidade, que nada mais é que a adoção de critérios legais e morais necessários para a melhor utilização dos recursos públicos, evitando desperdícios e garantindo maior rentabilidade social $^{22}$.

Relaciona-se, também, o princípio da eficiência ao da economicidade previsto no art. 70 da Constituição Federal, uma vez que se busca a melhor relação custo/benefício nas contratações administrativas. Porém, nesse sentido, o menor preço pode não se revelar como a melhor alternativa para a Administração Pública. É preciso que seja o menor preço dentre os bens e serviços que atinjam um padrão mínimo de qualidade ${ }^{23}$.

Pode-se entender a eficiência como uma exigência jurídica imposta à administração pública a fim de que essa atue de maneira "idônea, econômica e satisfatória na realização das finalidades públicas". Esses atributos qualificam a eficiência como a busca pela racionalidade e otimização dos meios, a fim de que se atinjam satisfatórios resultados dotados de qualidade, como fim ${ }^{24}$.

Destacando, também, a qualidade dos fins atingidos a partir dos gastos eficientes do poder público, juridicamente, o princípio da eficiência não se basta ao "razoável ou correto aproveitamento dos recursos e meios disponíveis em função dos fins prezados". Ou seja, apesar de ser um dever do administrador público a busca pelo ótimo, a eficiência não serve apenas para otimizar os meios, mas relaciona-se a "qualidade do agir final" 25 .

O conceito econômico de eficiência induz ao ótimo aproveitamento de recursos escassos a fim de realizar o máximo de resultados desejados, não sendo exigível, portanto, apenas a eficácia, ou seja, que o Estado alcance os resultados (finalidade) indiferente quanto

${ }^{20}$ COSTÓDIO FILHO, Ubirajara. Administração Pública (princípios). In: Dimitri Dimoulis. (Org.). Dicionário brasileiro de direito constitucional. São Paulo: Saraiva, 2a ed. 2012, p. 37.

21 ÁVILA, Humberto. Moralidade, razoabilidade e eficiência na atividade administrativa. Revista Eletrônica de Direito do Estado, n. 4, p. 1-25, out.-dez., 2005, p. 24. Disponível em: <http://www.direitodoestado.com.br/artigo/humberto-avila/moralidade-razoabilidade-e-eficiencia-naatividade-administrativa>. Acesso em: 04 jun. 2019.

${ }^{22}$ MORAES, Alexandre de. Direito Constitucional, 33a. ed. rev. e atual. até a EC no 95, de 15 de dezembro de 2016 - São Paulo: Atlas, 2017, p. 257.

${ }^{23}$ GARCIA, F. A.. Licitações e Contratos Administrativos-Casos e Polêmicas, 2a ed., Rio de Janeiro: Lumen Juris, 2009, p. 5.

${ }^{24}$ MODESTO, Paulo. Notas para um debate sobre o princípio constitucional da eficiência. Revista do Serviço Público, v. 51, n. 2, p. 105-119, abr.-jun. 2000, p. 112-113. Disponível em: < https://revista.enap.gov.br/index.php/RSP/article/view/328>. Acesso em 04 jun. 2019.

25 FREITAS, Juarez. O Controle dos Atos Administrativos e os Princípios Fundamentais, 2a ed., São Paulo: Malheiros, 1999, p. 85, 86. 
aos meios, mas que os atinja da melhor forma (eficiência) possível, tendo, assim, uma dimensão qualitativa. Dessa forma, conclui que "a eficiência diz respeito ao cumprimento das finalidades do serviço público, de molde a satisfazer necessidades dos usuários, do modo menos oneroso possível, extraindo-se dos recursos empregados a maior qualidade na sua prestação" 26 .

Essas conceituações apresentadas destacam a estreita relação do princípio da eficiência com a economia, partindo da definição econômica do princípio, que entende a eficiência como a "aptidão para obter o máximo ou o melhor resultado ou rendimento, com a menor perda ou o menor dispêndio de esforços" 27 .

A literatura administrativa faz distinção entre eficiência e eficácia. Chiavenato, por exemplo, aponta a eficácia como um fim, "uma medida de alcance de resultados", enquanto a eficiência é apontada como um meio, "uma medida da utilização dos recursos nesse processo". Acrescenta, ainda, que a "eficiência é uma relação entre custos e benefícios, ou seja, uma relação entre recursos aplicados e produto final obtido" 28.

Apesar disso, defende-se que o princípio da eficiência está intimamente relacionado ao conceito de eficácia, pois na promoção do bem comum a administração deve recorrer tanto aos meios como aos resultados. Assim, o princípio da eficiência é bipotencial, pois volta sua ação jurídica tanto para a ação instrumental realizada, como para o resultado por ela obtido. Portanto, o princípio exige tanto o aproveitamento máximo das potencialidades existentes, isto é, dos recursos escassos que a coletividade possui, como o resultado quantitativa e qualitativamente otimizado, no que concerne ao atendimento das necessidades coletivas ${ }^{29}$.

\section{CONCEITUANDO DESENVOLVIMENTO}

A primeira conceição de desenvolvimento remete ao efeito de crescer, evoluir, progredir. A origem biológica do termo adveio do entendimento de desenvolvimento como ação de transformar. Posteriormente, a migração do termo do campo biológico para o social, admitiu a aplicação da mesma ideia de progresso, crescimento e expansão à sociedade. Assim, desenvolvimento atingiu a concepção de pôr em movimento um processo de mudança que faz evoluir a sociedade para um estado superior ${ }^{30}$.

A ideia de progresso vinculado ao termo desenvolvimento não é nova. Esse conceito remonta a antiga sociedade grega e implica dizer que a sociedade se move em direção a uma

\footnotetext{
${ }^{26}$ GROTTI, Dinorá Adelaide Mussetti. O Serviço público e a constituição brasileira de 1988. São Paulo: Malheiros, 2003, p. 298-299.

${ }^{27}$ SZTAJN, Raquel. Law and Economics. In: Zylbersztajn, Décio; Sztajn, Raquel. (Org.). Direito e economia: Análise Econômica do Direito e das Organizações, 6a edição, Rio de Janeiro: Campus, 2005, p. 83.

${ }^{28}$ CHIAVENATO, Idalberto. Introdução à teoria geral da administração: uma visão abrangente da moderna administração das organizações. 7ạ. ed. rev. e atual. 6ạ reimp. Rio de Janeiro: Campus/Elsevier, 2003, p. 155.

${ }^{29}$ BATISTA JÚNIOR, Onofre Alves. Princípio constitucional da eficiência administrativa. 2a ed. Belo Horizonte: Fórum, 2012, p 99.

30 SANTOS, Elinaldo Leal et al. Desenvolvimento: Um Conceito Multidimensional. Desenvolvimento Regional em debate, Revista Eletrônica do Programa de Mestrado em Desenvolvimento Regional da Universidade do Contestado, v. 2, p. 44-61-61, 2012, p. 45-47. Disponível em: < http://recipp.ipp.pt/bitstream/10400.22/1858/1/ART_ElinaldoSantos_2012.pdf>. Acesso em 04 jun. 2019.
} 
condição melhor que a de onde partiu, pois essa posição é mais benéfica e produz existências mais felizes ${ }^{31}$.

A Constituição Federal de 1988 textualmente atribuiu ao Estado brasileiro o papel de garantidor do desenvolvimento nacional ${ }^{32}$. Embora não posicionado constitucionalmente como tal, reconhece-se o direito ao desenvolvimento como direito fundamental decorrente, valendo-se da disposição do §2으, art. 5으, da CRFB/1988 ${ }^{33}$. A doutrina defende o direito ao desenvolvimento como parte integrante dos direitos fundamentais de terceira dimensão ${ }^{34}$.

Após a segunda guerra mundial surgiu uma preocupação prática com o crescimento econômico. As economias prejudicadas pela guerra estavam em processo de reconstrução, os países subdesenvolvidos se esforçavam para iniciar o seu desenvolvimento econômico, os países capitalistas avançados concentravam seus esforços em aumentar a taxa de crescimento a longo prazo, e, os países socialistas estavam decididos a alcançar as economias capitalistas através de uma rápida expansão econômica. O interesse, à época, era notadamente o crescimento econômico, e, talvez por isso, o conceito de desenvolvimento tenha estado por tanto tempo a esse atrelado ${ }^{35}$.

É bem verdade que o Estado somente terá condições de atingir seus objetivos se conseguir impulsionar o crescimento econômico. Mas, é preciso atentar-se às outras concepções e dimensões do desenvolvimento ${ }^{36}$.

Há muito existe uma discussão econômica mais ampla, pois há economistas que defendem a inter-relação da ciência econômica com outras áreas do conhecimento, não sendo a busca pela riqueza um fim, mas antes um instrumento ${ }^{37}$.

Há muito se defende que o desenvolvimento deve ser medido através da análise do bem-estar disponível a uma população e não frente à renda per capita ${ }^{38}$.

Para Amartya Sen, o desenvolvimento está relacionado à melhora da vida e das liberdades desfrutadas, de maneira que a maximização da renda ou riqueza não é o objetivo básico do desenvolvimento ${ }^{39}$.

O desenvolvimento do Estado, portanto, depende do desenvolvimento dos direitos fundamentais do cidadão. À parte disso, o crescimento econômico apenas fará sentido para

\footnotetext{
${ }^{31}$ DUPAS, Gilberto. O Mito do Progresso. São Paulo: Editora UNESP, 2006.

${ }^{32}$ Cf. art. 3, inc. II, CRFB/1988.

33 OLIVEIRA, Gustavo Henrique Justino. Direito ao desenvolvimento na constituição brasileira de 1988. Revista Eletrônica de Direito Administrativo e Econômico, Salvador, n. 16, nov./jan., 2009. p. 12. Disponível em $<$ http://www.direitodoestado.com.br/artigo/gustavo-henrique-justino-de-oliveira/direito-ao-desenvolvimentona-constituicao-brasileira-de-1988>. Acesso em 04 jun. 2019.

${ }^{34}$ NOVELINO, Marcelo. Direito Constitucional. São Paulo: Método, 2009, 3ạ ed., p. 362-364.

${ }^{35}$ SEN, Amartya Kumar. Economía del crecimiento. Trad. de Eduardo L. Suárez - México: Fondo de Cultura Económica, 1979, p. 8.

${ }^{36}$ OLIVEIRA, Gustavo Henrique Justino de. Direito ao desenvolvimento na constituição brasileira de 1988. Revista Eletrônica de Direito Administrativo e Econômico, Salvador, n. 16, nov./jan., 2009. p. 10. Disponível em: $<$ http://www.direitodoestado.com.br/artigo/gustavo-henrique-justino-de-oliveira/direito-ao-desenvolvimentona-constituicao-brasileira-de-1988> Acesso em 04 jun. 2019.

${ }^{37}$ SEN, Amartya Kumar. Desenvolvimento como liberdade. São Paulo: Companhia das Letras, 1999, p. 19.

38 DERANI, Cristiane. Direito Ambiental Econômico. 2o ed. rev. São Paulo: Max Limonard, 2001, p.32-34.

${ }^{39}$ SEN, Amartya Kumar. Desenvolvimento como liberdade. São Paulo: Companhia das Letras, 1999, p. 50-60.
} 
poucos. Por isso, determinada ação econômica só deve ser utilizada se servir como instrumento de desenvolvimento em sentido amplo ${ }^{40}$.

A ONU (Organizações das Nações Unidas), através da Resolução no 41/128 da Assembleia Geral das Nações Unidas de 4 de dezembro de 1986, estabeleceu um conceito amplo de desenvolvimento, apontando-o como "um processo econômico, social, cultural e político abrangente, que visa ao constante incremento do bem-estar de toda a população e de todos os indivíduos com base em sua participação ativa, livre e significativa no desenvolvimento e na distribuição justa dos benefícios daí resultantes"41.

Essa definição induz que o desenvolvimento é extensível a diferentes ramos do conhecimento e em todos esses é admitida a sua aplicabilidade.

Especificamente, a declaração sobre o direito ao desenvolvimento da ONU atribui aos Estados os deveres de: "formular políticas nacionais adequadas para o desenvolvimento, que visem ao constante aprimoramento do bem-estar de toda a população e de todos os indivíduos, com base em sua participação ativa, livre e significativa, e no desenvolvimento e na distribuição equitativa dos benefícios daí resultantes" (art. 2ㅇß3); de "tomar providências para eliminar os obstáculos ao desenvolvimento resultantes da falha na observância dos direitos civis e políticos, assim como dos direitos econômicos, sociais e culturais" (art. 60 §3); e de 'assegurar a igualdade de oportunidade para todos no acesso aos recursos básicos, educação, serviços de saúde, alimentação, habitação, emprego e distribuição equitativa da renda' (art. 8요).

Partindo desses deveres conferidos aos Estados, percebe-se que o desenvolvimento depende da superação dos 'obstáculos resultantes da inobservância dos direitos' que violam as liberdades básicas das pessoas ${ }^{42}$.

A privação dessas liberdades, ensina Sen, dá-se em razão da "pobreza e tirania, carência de oportunidades econômicas e destituição social sistemática, negligência de serviços públicos e intolerância ou interferência excessiva de Estados repressivos" ${ }^{43}$.

Assim, o desenvolvimento constitui-se da expansão dessas liberdades à medida que elimina essas privações que limitam as escolhas e as oportunidades das pessoas, a fim de que as pessoas tenham melhora na vida que levam e nas liberdades que desfrutam ${ }^{44}$.

Liberdades, para Sen, são aquelas que conferem ao indivíduo a oportunidade de moldar o seu próprio destino ${ }^{45}$, o que só é possível se a esse forem garantidas as formas instrumentais de liberdades: liberdades políticas, facilidades econômicas, oportunidades sociais, garantia de transparência e segurança protetora ${ }^{46}$.

\footnotetext{
40 TAVARES, André Ramos. Direito constitucional econômico. São Paulo: Método, 2003, p. 68.

${ }^{41}$ Declaração sobre o direito ao desenvolvimento da ONU adotada pela Resolução n. 41/128 da Assembleia Geral das Nações Unidas em 04 dez. 1986. Disponível em:

<http://www.direitoshumanos.usp.br/index.php/Direito-ao-Desenvolvimento/declaracao-sobre-o-direito-aodesenvolvimento.html>. Acesso 04 jun. 2019.

${ }^{42}$ SEN, Amartya Kumar. Desenvolvimento como liberdade. 4a reimpressão, São Paulo: Companhia das Letras, 2010, p. 9.

43 Ibid., p. 16.

${ }^{44}$ Ibid., p. 10, 16, 29.

45 Ibid., p. 26, 77.

${ }^{46}$ Ibid., p. 58.
} 
Essas liberdades possuem uma interligação, de maneira que somente se tornam eficazes em decorrência de uma relação de causa e efeito, na qual uma liberdade promove a outra consequencialmente ${ }^{47}$.

A síntese do pensamento seniano é que "as liberdades não são apenas os fins primordiais do desenvolvimento, mas também os meios principais". As liberdades, portanto, são os meios e os fins para o desenvolvimento ${ }^{48}$.

Essa ponderação necessária entre os diferentes conceitos de desenvolvimento, fez surgir, à década de 1980, um conceito que dá uma idéia de equilíbrio a esse termo multidimensional.

O documento intitulado "Our Common Future", que ficou mais conhecido como Relatório Brundtland, publicado em 1987, demonstrou a necessidade de atentar não apenas para o presente, mas especialmente para o futuro. Nesse documento, a definição de desenvolvimento é empregada como aquele que "atende às necessidades do presente sem comprometer a possibilidade de as gerações futuras atenderem as suas próprias necessidades". Pela primeira vez utilizava-se o termo desenvolvimento sustentável ${ }^{49}$.

Sustentabilidade é toda ação que é destinada a manter as condições que sustentam os seres vivos, a fim de manter sua continuidade e atender as necessidades das gerações presentes e futuras ${ }^{50}$.

O desenvolvimento sustentável indica a necessidade de manter os alicerces da vida e atividades humanas, daí a preocupação com o ambiente em que vivem, para que as futuras gerações também tenham oportunidade de desfrutar dos mesmos recursos que hoje estão à disposição ${ }^{51}$.

Conclui-se que para alcançar a plenitude das liberdades humanas é necessário o equilíbrio entre as demais dimensões do desenvolvimento, tendo que haver, em determinadas situações, a ponderação $0^{52}$.

Essa ponderação permite que determinadas ações sejam praticadas, mesmo ao custo de dano ambiental, como a construção de uma hidrelétrica, por exemplo. Notadamente, a ponderação prévia atribui maior peso a necessidade de fornecimento de energia elétrica, que a de se preservar o ambiente ${ }^{53}$.

\footnotetext{
47 Ibid., p. 57.

48 Ibid., p. 10, 25, 54.

${ }^{49}$ CMMAD - Comissão mundial sobre meio ambiente e desenvolvimento -. Nosso futuro comum. 2a ed. Rio de Janeiro: FGV, 1988, p. 46.

${ }^{50}$ BOFF, Leonardo. Sustentabilidade: o que é - o que não é. Petrópolis, Rio Fe Janeiro: Vozes, 2012, p. 32

${ }^{51}$ FIORILLO, C. A. P.; DIAFÉRIA, A.. Biodiversidade e patrimônio genético no Direito Ambiental brasileiro. São Paulo: Max Limonad, 1999, p. 31.

52 JARDIM, Jean de Sousa. Desenvolvimento sustentável, desenvolvimento como liberdade e a construção da cidadania na perspectiva ambiental. Revista do Programa de Mestrado em Direito do Uniceub, v. 2, n.1, p. 189201, 2005. p. 199. Disponível em: < https://www.publicacoesacademicas.uniceub.br/prisma/article/view/187>. Acesso em 04 jun. 2019.

${ }^{53}$ VIEGAS, Eduardo Coral. O desenvolvimento sustentável como sobreprincípio. In: Antônio Herman Benjamin; Eládio Lecey; Sílvia Cappelli. (Org.). Mudanças climáticas, biodiversidade e uso sustentável de energia. 1ed. São Paulo: Imprensa Oficial do Estado de São Paulo, v. 1, p. 159-169, 2008, p. 161-162.
} 
No entanto, a necessidade de preservação do ambiente é atualmente indiscutível. Por isso, busca-se prioritariamente evitar a ocorrência de danos ambientais ao máximo possível. Porém, diante de uma inevitável ação prejudicial ao ambiente, emprega-se o máximo esforço para que o dano seja o mínimo possível. Seguindo essa lógica, haverá a maximização da proteção ambiental sem que isso cause prejuízo ao desenvolvimento econômico ${ }^{54}$.

Percebe-se, portanto, que inicialmente o desenvolvimento esteve atrelado ao crescimento econômico, entretanto, diante das análises pluralistas do conceito assumiu ares multidimensionais que o consignaram como processo de progresso abrangente às áreas social, cultural, política e econômica, cujo valor maior não é apenas a maximização do bem estar individual e coletivo, mas também, o aumento das liberdades instrumentais que servem, ao mesmo tempo, conforme Sen, como meio e fim ao desenvolvimento.

\section{EFICIÊNCIA COMO INSTRUMENTO DE DESENVOLVIMENTO}

Usualmente, instrumento é o meio para se obter algo, uma ferramenta ou objeto que serve de auxílio ou é empregado para conseguir um resultado.

Empregar a eficiência como um instrumento de desenvolvimento significa afirmar que a eficiência pode servir como objeto de auxílio, como ferramenta, ou como meio de se atingir o desenvolvimento.

No entanto, existem críticas à ideia de eficiência como instrumento ou objeto de desenvolvimento.

Alguns juristas questionam a eficiência como princípio aplicável ao sistema jurídico, por entender ser esse incompatível com o ordenamento jurídico brasileiro. Brockmann Moreira defende que não se deve aplicar um parâmetro que advêm do setor privado - cujo objetivo é o lucro - ao interesse público, partindo da ideia de que a eficiência não é, pois, "princípio jurídico, muito menos poderia ser alçado à condição de norma constitucional" 55 .

Bandeira de Mello segue o pensamento do italiano Guido Falzone, e, entende que o princípio da eficiência está para os brasileiros como o princípio da boa administração está para os italianos, não sendo aplicável, portanto, as características econômicas da eficiência, uma vez que seria um contraponto ao princípio da legalidade ${ }^{56}$.

Não é preciso muito para entender que os critérios de eficiência econômica, como os de Pareto e Kaldor Hicks apresentados, distanciam-se de posições morais e filosóficas, à medida que a economia moderna tem se apegado à técnica em detrimento de discussões mais amplas. De forma que, assim como sugere Sen, a eficiência como um norte é questionável,

\footnotetext{
54 Ibid.

${ }^{55}$ MOREIRA, Egon Bockmann.. Processo administrativo: Princípios Constitucionais e a Lei 9.784/1999. 2a Ed. Malheiros: São Paulo, 2000, p. 320-341.

${ }^{56}$ BANDEIRA DE MELLO, Celson Antônio. Curso de Direito Administrativo. São Paulo: Malheiros, 30ạ edição, 2013, p. $112-113,125$.
} 
pois o que parece eficiência hoje pode não ser amanhã, bastando para isso uma mudança de prioridades ou objetivos ${ }^{57}$.

Essas teorias são apresentadas sob o enfoque utilitarista da eficiência, cuja forma de avaliação se baseia na relação de satisfação ou felicidades resultantes ${ }^{58}$. De maneira que as escolhas das ações, sob o viés utilitarista, são tomadas após análise dos benefícios consequentes em termos de bem-estar ${ }^{59}$.

A abordagem utilitarista clássica, como ensinada, é obtida através da maximização da utilidade dos indivíduos, que por gravidade implica na maximização do bem-estar da sociedade, à medida que são somadas as utilidades individuais ${ }^{60}$.

Amartya Sen contesta a validade do utilitarismo como critério de desenvolvimento, apontando as seguintes limitações: 'o cálculo utilitarista tende a não levar em consideração desigualdades na distribuição da felicidade; desconsidera direitos e liberdades, uma vez que são valorizados apenas indiretamente e somente no grau em que influenciam as utilidades; e não mostra ser um critério sólido, pois é facilmente influenciável' ${ }^{61}$.

Ou seja, para Sen o critério utilitarista de elevação do bem-estar não é um critério confiável por ser limitado, omitindo-se quanto à distributividade, e, porque pode ser injusto com os desfavorecidos, em razão de esses possuírem demasiada tendência ao conformismo, já que aprenderam a sobreviver como podem, não tendo, pois, "coragem de exigir alguma mudança radical, chegando mesmo a ajustar seus desejos e expectativas àquilo que sem nenhuma ambição consideram exequível" 62 .

Quanto à distributividade, Sen afirma que um estado pode aplicar o ótimo de Pareto, ou seja, maximizar o bem-estar social até a medida de tornar impossível o aumento do bemestar de um indivíduo sem que isso implique na piora do bem-estar de outro, na mesma medida que pode haver algumas pessoas na miséria extrema e outras nadando em luxo, desde que os miseráveis não possam melhorar suas condições sem reduzir o luxo dos $\operatorname{ricos}^{63}$.

Seguindo esse entendimento, também é possível aplicar o critério de Kaldor-Hicks, de maneira que o benefício total seja maior que o custo total inicial, resultando numa evidente melhora global, tornando uma medida economicamente eficiente ao mesmo tempo que

\footnotetext{
57 NIED, Paulo Sérgio. O conceito de eficiência econômica e a ruptura do contrato de sociedade. In: XXI Encontro Nacional do CONPEDI, 2012, Uberlândia. Anais do XXI Encontro Nacional do CONPEDI. Florianópolis: Fundação Boiteux, 2012, p. 4297-4314.

58 "Na forma clássica do utilitarismo, como desenvolvido particularmente por Jeremy Bentham, define-se a utilidade como prazer, felicidade ou satisfação, e portanto tudo gira em torno dessas realizações mentais. Questões potencialmente importantíssimas como liberdade substantiva individual, a fruição ou a violação de direitos reconhecidos e aspectos de qualidade de vida não são refletidos de forma adequada nas estatísticas sobre prazer não podem influenciar diretamente uma avaliação normativa nessa estrutura utilitarista". SEN, Amartya Kumar. Desenvolvimento como liberdade. 4a reimpressão, São Paulo: Companhia das Letras, 2010, p. 81.

${ }^{59}$ SEN, A.. WILLIANS, B.. Utilitarism and beyond. Cambridge University Press, 1982, p. 3, 4.

${ }^{60}$ NEUBERGER, D.; MARIN, S. R.. Algumas contribuições de Amartya Sen aos conceitos de 'eficiência' e 'equidade'. In: IV Seminário de Ciências Sociais Aplicadas, 2014, Criciúma - SC. Anais do IV Seminário de Ciências Sociais Aplicadas, v. 04, 2014, p. 165.

${ }^{61}$ SEN, Amartya Kumar. Desenvolvimento como liberdade. 4a reimp., São Paulo: Companhia das Letras, $2010, \mathrm{p}$. $88,89$.

62 lbid., p. 89.

${ }^{63}$ Id. Sobre Ética e Economia. Companhia das Letras. 7ạ ed. São Paulo. 2008, p. 48.
} 
encoraja o aumento da desigualdade entre ricos e pobres, pois é possível manter pessoas na miséria extrema e outras nadando em luxo, desde que haja melhora no bem-estar global, de tal maneira, que ao menos em tese, haja a possibilidade de compensação ao prejudicado.

A crítica formulada sugere uma abordagem monista ao utilitarismo, em decorrência de sua abordagem valorativa do bem-estar sem que seja dada a devida consideração a ampliação das liberdades e direitos dos indivíduos ${ }^{64}$.

Por esses motivos o Estado não pode se valer da eficiência econômica a qualquer custo. Como já mencionado, o objetivo empregado aos conceitos econômicos é fazer uma releitura do sistema jurídico, valendo-se de regras e princípios econômicos como orientadores, não como doutrinadores ${ }^{65}$.

Apesar de estabelecer que não se trata de uma característica predominante, Amartya Sen reconhece a importância do desenvolvimento econômico na melhora da qualidade de vida das pessoas, pois a falta de renda implica em privações de capacidade, da mesma forma que os investimentos em garantias de liberdades influenciam no seu aumento ${ }^{66}$.

O desenvolvimento não é apenas o resultado do crescimento econômico, mas não há desenvolvimento sem que haja melhora substancial no aspecto econômico, pois a melhora da qualidade de vida depende da alocação dos recursos de maneira eficiente pelos diferentes setores da economia ${ }^{67}$.

Oliveira afirma que o desenvolvimento é o crescimento econômico "transformado para satisfazer as mais diversificadas necessidades do ser humano, tais como: saúde, educação, habitação, transporte, alimentação, lazer, dentre outras". Apesar das controvérsias existentes, o crescimento econômico não é suficiente, mas é "um requisito para superação da pobreza e para construção de um padrão digno de vida" 68.

Por isso, o grande questionamento é como fazer um bom uso dos recursos econômicos a fim de atender adequadamente os interesses dos indivíduos.

A eficiência possui duas vertentes, uma referente à estruturação da máquina estatal a fim de torná-la racional para que as necessidades da sociedade sejam melhores satisfeitas e outra referente ao desempenho dos agentes públicos, a fim de que atinjam os melhores resultados possíveis ${ }^{69}$.

\footnotetext{
${ }^{64}$ NEUBERGER, D.; MARIN, S. R.. Algumas contribuições de Amartya Sen aos conceitos de 'eficiência' e 'equidade'. In: IV Seminário de Ciências Sociais Aplicadas, 2014, Criciúma - SC. Anais do IV Seminário de Ciências Sociais Aplicadas, v. 04, 2014, p. 172.

${ }^{65}$ COOTER, R.; ULEN, T.. Direito \& Economia. 5 ed. Tradução Luis M. Sander e Francisco Araújo da Costa. Porto Alegre: Bookman, 2010, p. 25-33.

66 Ibid., p. 35, 59, 61.

${ }^{67}$ VASCONCELOS, M. A.; GARCIA, M. E.. Fundamentos de economia. São Paulo: Saraiva, 1998, p. 205.

${ }^{68}$ OLIVEIRA, Gilson Batista. Uma discussão sobre o conceito de desenvolvimento. Revista da FAE, Curitiba, v. 1, p. 37-48, 2002, p. 40, 41. Disponível em: <https://revistafae.fae.edu/revistafae/article/view/477>. Acesso em 04 jun. 2019.

${ }^{69}$ MARTINS, Cristiane Fortes Nunes. O Princípio da Eficiência na Administração Pública. FAETE, 2012. Disponível em: $\quad$ http://www.egov.ufsc.br:8080/portal/conteudo/o-princ\%C3\%ADpio-da-efici\%C3\%AAncia-naadministra\%C3\%A7\%C3\%A3o-p\%C3\%BAblica>. Acesso em 04 jun. 2019.
} 
Mendes visualiza a eficiência como um princípio alertador, servido como limitador dos vícios que sabidamente existem na máquina pública, na medida que sobrevalorizam os meios e sacrificam os fins, razão e a serviço dos quais, a eficiência, vem a ser instituída ${ }^{70}$.

Assim, pode-se concluir que o princípio da eficiência foi inserido na Constituição em razão da preocupação do constituinte reformador com o desempenho da administração pública. A ênfase passou a ser a busca pelos melhores resultados ${ }^{71}$.

Diante da necessidade de reduzir custos e aumentar a qualidade dos serviços administrativos, não apenas tornou-se essencial a eficiência da administração pública, como a reforma do aparelho estatal passou a ser, por esses valores orientada ${ }^{72}$.

A administração eficiente é a que atende às necessidades reais dos cidadãos com o menor custo, favorecendo a concorrência e promovendo os serviços de maior qualidade ${ }^{73}$.

Essa definição de eficiência está em harmonia com a apresentada, na qual para uma medida ser considerada economicamente eficiente precisa atender a uma destas duas condições: não ser possível atingir o mesmo resultado a um custo menor ou não ser possível alcançar melhores resultados com o mesmo custo $^{74}$.

A eficiência serve como objeto de desenvolvimento à medida que, na lição de Alexandre de Moraes impõe à administração pública e a seus agentes "a persecução do bem comum, por meio do exercício de suas competências de forma imparcial, neutra, transparente, participativa, eficaz, sem burocracia e sempre em busca da qualidade, primando pela adoção de critérios legais e morais necessários para a melhor utilização possível de recursos públicos, de maneira a evitar desperdícios e garantir-se uma maior rentabilidade social" 75 .

Como restou demonstrado no primeiro tópico, à eficiência serve como meio. Mas, esse meio não se restringe a ausência de desperdício de recursos, o que significaria economicidade, apenas. De forma que a eficiência somente se mostrará efetiva quando a ação administrativa atingir o seu fim e propiciar a eficácia pretendida ${ }^{76}$.

\footnotetext{
${ }^{70}$ MENDES, G. F.; COELHO, I. M.; GONET, P. G. B.. Curso de Direito Constitucional, São Paulo: Saraiva, 2007, p. 788.

${ }^{71}$ Id., 2013, p. 826.

72 PALUDO, Augustinho Vicente. Administração Pública: teorias e questões. Rio de Janeiro: Elsevier, 2012, p. 66.

${ }^{73}$ SÁNCHEZ, Isabel María García. La nueva gestión pública: evolución y tendencias. Presupuesto y Gasto Público 47/2007: 37-64. Secretaría General de Presupuestos y Gastos. Instituto de Estudios Fiscales. Universidad de Salamanca, p. 44. Disponível em: <https://dialnet.unirioja.es/servlet/articulo?codigo=2341565>. Acesso em 04 jun. 2019.

${ }^{74}$ COOTER, R.; ULEN, T.. Direito \& Economia. 5 ed. Tradução Luis M. Sander e Francisco Araújo da Costa. Porto Alegre: Bookman, 2010, p. 38.

${ }^{75}$ MORAES, Alexandre de. Direito Constitucional. 33a ed. rev. e atual. até a EC no 95, de 15 de dezembro de 2016 - São Paulo: Atlas, 2017, p. 260, 261.

76 MORAIS, Janaína Jacolina. Princípio da Eficiência na Administração Pública. Disponível em: <http://www.eduvaleavare.com.br/wp-content/uploads/2014/07/principio_eficiencia.pdf>. Acesso em 04 jun. 2019.
} 
Dessa forma, a escolha de meios adequados para promover seus fins não é suficiente. A eficiência requer a satisfatoriedade dos fins. Ou seja, escolher a melhor maneira de realizar algo irrelevante, insignificante ou indesejado não se coaduna com a eficiência ${ }^{77}$.

Reconhece-se, pois, que o crescimento econômico fornece subsídios ao Estado para que esse adquira os recursos necessários para implantar suas políticas públicas. Mas, é a aplicação eficiente dos recursos públicos que permite a redução dos gargalos institucionais causadores dos desperdícios, possibilitando o aumento dos recursos do Estado, que podem, então, ser reinvestidos em benefício da sociedade.

Além disso, a eficiência ainda é imprescindível em outro aspecto: quando há degeneração da intenção dos agentes públicos na aplicação dos recursos. Por óbvio, se os recursos são escassos, desviá-los dos seus objetivos constitucionais é uma restrição maldosa das liberdades individuais dos cidadãos. Daí a importância da busca pela aplicação eficiente do direito.

\section{A EFICIÊNCIA E O DIREITO: UM EXEMPLO}

Jean-Jacques Rousseau atribuiu à origem da relação social como a conhecemos, ao momento em que um sujeito ao cercar um lote de terra se pôs a dizer: "Isto é meu", encontrando pessoas suficientemente dispostas a lhe dar crédito. Para Rousseau, a sociedade surgira da necessidade humana de proteger aquilo que imagina ser seu ${ }^{78}$.

O homem era absolutamente livre em seu estado de natureza. Porém, fora necessário uma imposição limítrofe dessa liberdade. Sendo essa imposta e necessária em virtude da racionalização efetivamente econômica da proteção da propriedade privada. A necessidade humana de acumular bens gerava instabilidade e conflitos. Sendo, portanto, demasiadamente oneroso o custo da exclusão de terceiros daquilo que se entendia como privado. Para superar essa condição, os homens abriram mão de parte de seu poder, instituindo um poder maior e pleno, o poder do Estado, que era, por derradeiro, proprietário absoluto; assim, apenas por sua concessão e proteção era garantido o direito de propriedade aos particulares ${ }^{79}$.

Em suma, o que se pretende apontar é que a formação da sociedade civil teve como fundamento a necessidade de se ter eficiência na proteção dos bens privados. Em algum momento na história, fora imprescindível que houvesse um equilíbrio entre o desejo humano de ter algo e o custo oneroso de proteger - excluir terceiros do usufruto - ao custo da força. Em algum momento, as pessoas firmaram um pacto social, com regras definidas sobre direitos e obrigações, designando um poder maior, o poder do Estado, para garantir o cumprimento

77 ÁVILA, Humberto. Moralidade, razoabilidade e eficiência na atividade administrativa. Revista Eletrônica de Direito do Estado, n. 4, p. 1-25, out.-dez., 2005, p. 24. Disponível em: <http://www.direitodoestado.com.br/artigo/humberto-avila/moralidade-razoabilidade-e-eficiencia-naatividade-administrativa>. Acesso em: 04 jun. 2019.

78 ROUSSEAU, Jean-Jacques. Discurso sobre a origem e os fundamentos da desigualdade entre os homens. São Paulo: Martin Claret, 2005, p. 27.

${ }^{79}$ CABRAL. Rodolfo de Carvalho. Direito à terra e trabalho: o Movimento dos Trabalhadores Rurais Sem Terra e a crítica da estrutura fundiária brasileira. 207 f. Dissertação (Mestrado em Direito) - Programa de Pós Graduação em Direito - Centro de Ciências Jurídicas/FDR, Universidade Federal de Pernambuco, Recife, 2009, p. 41-42. 
desse pacto por meio da força respaldada pela outorga coletiva. Isso possibilitou o desenvolvimento da sociedade, uma vez que o Estado passou a ter o ônus de proteger os bens privados e as pessoas o de respeitar os limites impostos pelo Estado ${ }^{80}$.

O decurso do tempo não mudou o sistema patrimonialista o qual está montada a sociedade. Pelo contrário, o aperfeiçoamento das regras desse sistema desencadeou o sistema capitalista, instando a busca do lucro, da vantagem.

A busca ambiciosa pelo capital tem servido como combustível de um fenômeno antiético e imoral: a corrupção. Ao questionar os fundamentos capitalistas do mercado mundial, Santos Dias menciona que "a ética sucumbe ao lucro" 81.

O conceito de corrupção não é uno e a depender da abordagem utilizada chegar-se-á a uma explicação diferente. $O$ mesmo ocorre quanto às teorias de prevenção. Apesar da exposição seguinte, sabe-se que a corrupção não é apenas consequência da racionalização econômica do agente. Essa abordagem econômica tende a limitar a corrupção à órbita dos interesses patrimoniais, sem considerar a sua relação com processos sociais e simbólicos ${ }^{82}$. Por isso, é preciso deixar claro que a abordagem seguinte está limitada a uma análise econômica do complexo fenômeno, tendo em vista o contorno temático do presente artigo.

As pessoas tendem a fazer aquilo que lhes parece mais benéfico. Diante das muitas possibilidades, utilizam um raciocínio lógico, atribuindo valor a cada uma das suas opções. Evidentemente, a racionalidade incentiva à escolha da opção menos onerosa ${ }^{83}$.

Levitt \& Dubner caracterizam a corrupção como "um ato econômico: obter mais gastando menos". Por isso não são apenas os políticos ou grandes empresários que trapaceiam. É também aquela garçonete que não informa a gorjeta coletiva e o aluno que cola do colega vizinho para usurpar um rendimento que efetivamente não the é merecido ${ }^{84}$.

A abordagem econômica destaca que corromper-se ou não é uma questão de escolha e as decisões são dotadas de valor. Uma escolha racional tende a maximizar a utilidade dos benefícios dessa decorrente. Assim, a escolha racional envolve uma prévia análise dos custos e benefícios e a maximização da eficiência econômica se dá à medida que os benefícios superam os custos ${ }^{85}$.

\footnotetext{
${ }^{80}$ GARCIA, T.; DANTAS, T. K. S.. Justificativa econômica do direito à propriedade intelectual sob a ótica econômica de Cotter\&Ulen. In: 6th ISTI (International Symposium on Technological Innovation), 2015, Aracajú, SE. 6th ISTI (International Symposium on Technological Innovation), 2015, v. 3, p. 355.

${ }^{81}$ SANTOS DIAS, Maria das Graças dos. Direito e pós-modernidade. Revista Novos Estudos Jurídicos, v. 11, n. 1, 2006. Disponível em: <http://siaiweb06.univali.br/seer/index.php/nej/article/download/424/366>. Acesso em: 04 jun. 2019.

82 FILGUEIRAS, Fernando. A tolerância à corrupção no Brasil: uma antinomia entre normas morais e prática social. Campinas, $\quad$ v. 15, n. 2, p. 386-421, Nov. 2009. Disponível em: <http://www.scielo.br/scielo.php?script=sci_arttext\&pid=S0104-62762009000200005\&lng=en\&nrm=iso>. Acesso em 04 Jun. 2019.

${ }^{83}$ COOTER, R.; ULEN, T.. Direito \& Economia. 5 ed. Tradução Luis M. Sander e Francisco Araújo da Costa. Porto Alegre: Bookman, 2010, p. 23-24.

${ }^{84}$ LEVITT, S. D.; DUBNER, S. J.. Freakonomics: o lado oculto e inesperado de tudo que nos afeta. 7 ed. Trad. Regina Lyra. Rio de Janeiro: Elsevier, 2007, p. 23, 28.

85 COOTER, R.; ULEN, T.. Direito \& Economia. 5 ed. Tradução Luis M. Sander e Francisco Araújo da Costa. Porto Alegre: Bookman, 2010, p. 35-74.
} 
Na década de 1970, o Ford Pinto era um dos carros mais vendidos dos EUA. Mas, tinha um grave problema de segurança. O tanque de combustível do automóvel estava sujeito a explodir em caso de colisão. Mais de quinhentas pessoas morreram e outras tantas ficaram feridas em decorrência disso. Quando a empresa foi processada, veio a público que os engenheiros que projetaram o carro sabiam do defeito. Eles haviam feito uma análise econômica dos custos e benefícios de se fazer um recall em todos os automóveis já vendidos, tornando os carros mais seguros (equivalente a US\$ 137 milhões). Mas, também fizeram os cálculos relativos à quantidade de indenizações que, porventura, deveriam pagar as vítimas ou familiares das vítimas que ingressassem com uma ação judicial (equivalente a US\$ 49,5 milhões). A Ford "chegou à conclusão de que o custo de consertar o tanque não compensaria o benefício de um carro mais seguro" ${ }^{86}$.

Percebe-se que a análise econômica feita pela companhia foi o fator decisivo na decisão tomada. Por que esse exemplo é relevante? Cooter \& Ulen afirmam que "uma lei é uma obrigação apoiada por uma sanção estatal" 87 . Ora, se não havia uma sanção legal suficientemente capaz de incentivar a companhia a tomar uma atitude mais "social", de fato, de um ponto de vista puramente econômico, ela agiu corretamente. A companhia avaliou a situação e escolheu o que lhe era mais benéfico. A maximização econômica consiste na satisfação com o mínimo comprometimento de posses.

A lei da demanda, basicamente, consiste na relação inversamente proporcional entre preço e oferta. Sendo o preço, o qualificador necessário para designar a disposição do consumidor em adquirir o produto. Ou seja, à medida que o preço de um determinado produto diminui a busca por esse produto aumenta, e vice-versa. De forma que a precificação do produto está inteiramente relacionada com quanto o consumidor se dispõe a pagar ${ }^{88}$.

Os economistas relacionam os efeitos das sanções legais no comportamento das pessoas quando preveem que as pessoas reagem às sanções impostas pelas leis da mesma forma que os consumidores reagem aos preços dos produtos. Os consumidores consomem menos dos produtos mais caros e mais dos mais baratos. Assim, as pessoas tendem a cometer menos ilícitos cujas penas sejam mais duras, por simplesmente não estarem dispostas a pagar o preço.

Certamente, a garantia de baixo risco e alta lucratividade, desprendendo-se dos conceitos de ética e moral, é um grande incentivo para o ingresso em qualquer negócio, seja esse lícito ou não. Ou seja, a quantidade de negócios ilícitos, é diretamente proporcional à disposição do criminoso em pagar o preço. Isso significa que, agindo racionalmente, a pessoa que se envereda em uma negociação corrupta, chegou à conclusão, após uma análise econômica da situação, que os benefícios de sua atitude criminosa compensam o eventual risco de ser pego e condenado ${ }^{89}$.

Visto que as pessoas em geral, estão engajadas em obter a vantagem ou lucro, escolhem fazer, portanto, o que lhes parece ser mais benéfico. Este entendimento parte de uma análise econômica para apontar que as decisões que implicam em ações, mínimas ou

\footnotetext{
${ }^{86}$ SANDEL, Michael J.. Justiça - o que é fazer a coisa certa. 6a Edição, Rio de Janeiro: Civilização Brasileira, 2012, p. $57-58$.

87 COOTER, R.; ULEN, T.. Direito \& Economia. 5 ed. Tradução Luis M. Sander e Francisco Araújo da Costa. Porto Alegre: Bookman, 2010, p. 25.

88 Ibid., p. 41-49.

89 Ibid., p. 475.
} 
não, são dotadas de valor econômico. Uma vez sendo a corrupção, também uma questão de escolha, tem-se que é um ato econômico que consiste em obter mais gastando menos.

Assim, corromper-se é uma questão de escolha que se dá baseando-se, o indivíduo, na maximização da utilidade: uma relação entre o custo e o benefício resultante de sua atitude corrupta. A análise econômica do direito infere que as pessoas reagem às sanções legais como os consumidores reagem aos preços dos produtos. Ou seja, quando as pessoas se corrompem é porque não se sentem intimidadas pela sanção legal decorrente ou confiam na impunidade; estão dispostas a pagar o preço.

Assim, estão postos os elementos incentivadores à corrupção nas aquisições de bens e prestação de serviços à administração pública: a percepção da oportunidade de lucros extraordinários; a formação de conluio entre agente público e empresa (ou grupo de empresas); o abuso do poder discricionário por parte de agentes públicos para favorecer determinadas empresas; e o baixo valor esperado de eventuais punições' ${ }^{90}$.

Daí a necessária e imprescindível melhora de mecanismos de fiscalização (prevenção) e, consequentemente, de punição aos que se enveredam em condutas criminosas. Uma punição efetivamente mais severa, não apenas legalmente garantida, mas efetivamente executada, restringirá a ação daqueles que não estiverem dispostos a pagar o preço da corrupção.

A má gestão do dinheiro público tem consequências devastadoras para a sociedade, pois retira dos administrados a oportunidade de obterem melhores condições (qualidade) de vida. É justamente a falta dessas liberdades que lentificam o desenvolvimento de alguns países ${ }^{91}$.

Analisados os custos envolvidos, percebe-se que a política punitiva é menos eficiente que a preventiva, uma vez que é a sociedade quem paga pelo obstáculo ao desenvolvimento, perdendo as suas liberdades em detrimento dos recursos que deveriam ser investidos para promovê-la; no que seria capaz de servir ao seu objetivo: o desenvolvimento ${ }^{92}$.

A prevenção assume duas formas: ex ante, ou seja, impedindo a formação dos acordos ilícitos através da ameaça de aplicação imediata de pesadas sanções a fim de tornar a negociação corrupta instável e/ou não lucrativa; e ex post, ou seja, evitando a reiteração da conduta, de maneira que os agentes, além de serem induzidos a interromperem a conduta ilegal, também sofram a ameaça de aplicação de sanções ainda mais duras, caso sejam identificados como reincidentes ${ }^{93}$.

\footnotetext{
${ }^{90}$ CASTRO, Luciano I. de. Combate à Corrupção em Licitações Públicas. Madrid: WorkingPapers - Universidad Carlos III de Madrid, Documento de Trabajo 07-03, Serie de Economía 02, Abr. 2007, p. 3.

${ }^{91}$ SEN, Amartya Kumar. Desenvolvimento como liberdade. 4ạ reimpressão, São Paulo: Companhia das Letras, 2010, p. 54-76.

${ }^{92}$ GUIMARAES, Patrícia Borba Vilar. Contribuições teóricas para o direito e desenvolvimento. IPEA: Brasília, 2013, v. 1824, 2013, p. 12-15. Disponível em: <http://www.ipea.gov.br/portal/images/stories/PDFs/TDs/td_1824.pdf>. Acesso em 04 jun. 2019.

${ }^{93}$ LIRA, Bruno de Oliveira. Cartéis em licitação: utilizando a teoria dos leilões para avaliar a legislação licitatória nacional. 115 f. Dissertação (Mestrado em Direito) - Centro de Ciências Jurídicas/CCJ - Universidade Federal de Pernambuco, Recife, 2012, p. 46-47.
} 


\section{CONCLUSÕES}

A reforma administrativa realizada em meados dos anos 1990 elevou a eficiência a posição de princípio constitucional. Entre os objetivos estava conferir eficiência e qualidade aos serviços prestados pelo Estado, transformando a Administração Pública em um instrumento poderoso de desenvolvimento.

A crise fiscal impõe ao Estado o desafio de atuar como garantidor do desenvolvimento nacional diante da realidade de aumento dos gastos públicos e escassez de recursos. Resta evidente, portanto, a importante e necessária aplicação eficiente dos recursos públicos.

Dentre as muitas definições de eficiência apontadas, destaca-se a que the confere o emprego de racionalidade a medição e aplicação dos custos e utilidades que satisfazem as necessidades públicas. Os conceitos econômicos de eficiência destacam a visão do princípio como aquele que propicia atingir melhores resultados ao mesmo custo, ou melhor, a um custo menor, alcançando a solução ótima às finalidades públicas.

Assim, a eficiência é tida como a busca pela racionalidade e otimização dos meios, tendo como fim, a busca de resultados qualitativamente satisfatórios, o que explica a relação íntima entre eficácia e eficiência, sendo este um princípio bipotêncial, voltado tanto para os meios utilizados como para os resultados produzidos. Exige-se tanto o aproveitamento máximo das potencialidades existentes, como o resultado quantitativa e qualitativamente otimizado, no que concerne ao atendimento das necessidades coletivas.

A busca por melhores resultados indica progresso, crescimento, seguir em direção a uma condição melhor que a da partida, atingir um benefício maior; elementos esses integrantes da concepção de desenvolvimento.

Muitas discussões existem acerca do conceito de desenvolvimento. Mas o senso majoritário é que o desenvolvimento designa o progresso do bem-estar dos indivíduos, através da ampliação das liberdades em superação aos obstáculos resultantes da inobservância de direitos que violam as liberdades básicas das pessoas.

Apesar das críticas de que como princípio não é aplicável ao sistema jurídico, a eficiência revela-se como um congruente instrumento de desenvolvimento. Entretanto, os critérios de eficiência econômica, como os de Pareto e Kaldor Hicks apresentados, distanciamse de posições éticas. Por isso, o Estado não pode se valer da eficiência a qualquer custo. Como mencionado, o objetivo empregado aos conceitos econômicos é fazer uma releitura do sistema jurídico, valendo-se de regras e princípios econômicos como orientadores, não como doutrinadores.

Apesar das controvérsias existentes, o crescimento econômico não é suficiente, mas é um requisito para superação da pobreza e para construção de um padrão digno de vida, servindo como subsídio para satisfazer as mais diversificadas necessidades do ser humano.

Porém, com os recursos escassos, o grande questionamento é como fazer bom uso dos recursos do Estado. A Administração eficiente é a que atende às necessidades reais dos cidadãos com o menor custo, promovendo os serviços de maior qualidade.

Reconhece-se que o crescimento econômico fornece subsídios ao Estado para que esse adquira os recursos necessários para implantar suas políticas públicas. Mas, é a aplicação 
eficiente dos recursos públicos que permite a redução dos gargalos institucionais causadores dos desperdícios, possibilitando o aumento dos recursos do Estado, que podem, então, ser reinvestidos em benefício da sociedade.

Por fim, uma vez que analisada a corrupção como uma questão de escolha, a partir de uma análise prévia dos custos e benefícios dela resultante, nota-se que a garantia de baixo risco e alta lucratividade, a parte dos conceitos éticos, serve como grande incentivo para sua prática.

Por isso, faz-se necessário a melhora dos mecanismos de punição, tornando menos lucrativa, portanto, menos atrativa, quaisquer que seja a ação criminosa. Porém, a eficiência aduz que o custo/benefício da prevenção demonstra maior eficácia, à medida que a punição é uma medida que não diminui os efeitos já consagrados pela corrupção, a saber, a perda das liberdades dos indivíduos prejudicados em detrimento dos recursos que deveriam ser investidos para promovê-las.

\section{REFERÊNCIAS}

ÁVILA, Humberto. Moralidade, razoabilidade e eficiência na atividade administrativa. Revista Eletrônica de Direito do Estado, n. 4, p. 1-25, out.-dez., 2005. Disponível em: $<$ http://www.direitodoestado.com.br/artigo/humberto-avila/moralidade-razoabilidade-eeficiencia-na-atividade-administrativa>. Acesso em: 04 jun. 2019.

BANDEIRA DE MELLO, Celso Antônio. Curso de Direito Administrativo. São Paulo: Malheiros, 30a edição, 2013.

Curso de Direito Administrativo. São Paulo: Malheiros, 32ạ edição, 2015.

BATISTA JÚNIOR, Onofre Alves. Princípio constitucional da eficiência administrativa. 2a ed. Belo Horizonte: Fórum, 2012.

BOFF, Leonardo. Sustentabilidade: o que é - o que não é. Petrópolis, Rio Fe Janeiro: Vozes, 2012.

CABRAL. Rodolfo de Carvalho. Direito à terra e trabalho: o Movimento dos Trabalhadores Rurais Sem Terra e a crítica da estrutura fundiária brasileira. 207 f. Dissertação (Mestrado em Direito) - Programa de Pós Graduação em Direito - Centro de Ciências Jurídicas/FDR, Universidade Federal de Pernambuco, Recife, 2009.

CASTRO, Luciano I. de. Combate à Corrupção em Licitações Públicas. Madrid: WorkingPapers - Universidad Carlos III de Madrid, Documento de Trabajo 07-03, Serie de Economía 02, Abr. 2007.

CHIAVENATO, Idalberto. Introdução à teoria geral da administração: uma visão abrangente da moderna administração das organizações. 7ạ. ed. rev. e atual. 6ạ reimp. Rio de Janeiro: Campus/Elsevier, 2003.

CMMAD - Comissão mundial sobre meio ambiente e desenvolvimento -. Nosso futuro comum. 2a ed.Rio de Janeiro: FGV, 1988. 
COOTER, R.; ULEN, T.. Direito \& Economia. 5 ed. Tradução Luis M. Sander e Francisco Araújo da Costa. Porto Alegre: Bookman, 2010.

COSTÓDIO FILHO, Ubirajara. Administração Pública (princípios). In: Dimitri Dimoulis. (Org.). Dicionário brasileiro de direito constitucional. São Paulo: Saraiva, 2a ed. 2012.

DERANI, Cristiane. Direito Ambiental Econômico. 2ำed. rev. São Paulo: Max Limonard, 2001.

DI PIETRO, Maria Sylvia Zanella. Direito administrativo. 32. ed. - Rio de Janeiro: Forense, 2019.

DUPAS, Gilberto. O Mito do Progresso. São Paulo: Editora UNESP, 2006.

FILGUEIRAS, Fernando. A tolerância à corrupção no Brasil: uma antinomia entre normas morais e prática social. Campinas, v. 15, n. 2, p. 386-421, Nov. 2009. Disponível em: $<$ http://www.scielo.br/scielo.php?script=sci_arttext\&pid=S0104-

62762009000200005\&lng=en\&nrm=iso>. Acesso em 04 Jun. 2019.

FIORILLO, C. A. P.; DIAFÉRIA, A.. Biodiversidade e patrimônio genético no Direito Ambiental brasileiro. São Paulo: Max Limonad, 1999.

FRANÇA, Vladimir da Rocha. Eficiência administrativa na Constituição Federal. Revista de Direito Administrativo, Rio de Janeiro, v. 220, p. 165-177, abr. 2000. ISSN 2238-5177. Disponível em: <http://bibliotecadigital.fgv.br/ojs/index.php/rda/article/view/47532>. Acesso em: 04 Jun. 2019.

FREITAS, Juarez. O Controle dos Atos Administrativos e os Princípios Fundamentais, 2a ed., São Paulo: Malheiros, 1999.

FONSECA, João Bosco Leopoldino da. Direito econômico. 9. ed. rev., atual., e ampl. - Rio de Janeiro: Forense, 2017.

GARCIA, F. A.. Licitações e Contratos Administrativos-Casos e Polêmicas, 2ª ed., Rio de Janeiro: Lumen Juris, 2009.

GARCIA, T.; DANTAS, T. K. S.. Justificativa econômica do direito à propriedade intelectual sob a ótica econômica de Cotter\&Ulen. In: 6th ISTI (International Symposium on Technological Innovation), 2015, Aracajú, SE. 6th ISTI (International Symposium on Technological Innovation), 2015, v. 3.

GROTTI, Dinorá Adelaide Mussetti. O Serviço público e a constituição brasileira de 1988. São Paulo: Malheiros, 2003.

GUIMARAES, Patrícia Borba Vilar. Contribuições teóricas para o direito e desenvolvimento. IPEA: Brasília, 2013, v. 1824, 2013, p. 12-15. Disponível em: <http://www.ipea.gov.br/portal/images/stories/PDFs/TDs/td_1824.pdf>. Acesso em 04 jun. 2019.

HÄRGER, Marcelo. Reflexões Iniciais sobre o Princípio da Eficiência, Revista de Direito Administrativo, Rio de Janeiro: Renovar, n. 217, p.151-161, dez. 1999.

JARDIM, Jean de Sousa. Desenvolvimento sustentável, desenvolvimento como liberdade e a construção da cidadania na perspectiva ambiental. Revista do Programa de Mestrado em Direito do Uniceub, v. 2, n.1, p. 189-201, 2005. Disponível em: <https://www.publicacoesacademicas.uniceub.br/prisma/article/view/187>. Acesso em 04 jun. 2019. 
LIRA, Bruno de Oliveira. Cartéis em licitação: utilizando a teoria dos leilões para avaliar a legislação licitatória nacional. 115 f. Dissertação (Mestrado em Direito) - Centro de Ciências Jurídicas/CCJ - Universidade Federal de Pernambuco, Recife, 2012.

LEVITT, S. D.; DUBNER, S. J.. Freakonomics: o lado oculto e inesperado de tudo que nos afeta. 7 ed. Trad. Regina Lyra. Rio de Janeiro: Elsevier, 2007.

MARTINS, Cristiane Fortes Nunes. O Princípio da Eficiência na Administração Pública. FAETE, 2012. Disponível em: <http://www.egov.ufsc.br:8080/portal/conteudo/o-princ\%C3\%ADpioda-efici\%C3\%AAncia-na-administra\%C3\%A7\%C3\%A3o-p\%C3\%BAblica>. Acesso em 04 jun. 2019.

MEDAUAR, Odete. Direito Administrativo moderno. Belo Horizonte: Fórum, 21ạ edição, 2018. MENDES, G. F.; COELHO, I. M.; GONET, P. G. B.. Curso de Direito Constitucional, São Paulo: Saraiva, 2007.

., Curso de Direito Constitucional, São Paulo: Saraiva, 2013.

MODESTO, Paulo. Notas para um debate sobre o princípio constitucional da eficiência. Revista do Serviço Público, v. 51, n. 2, p. 105-119, abr.-jun. 2000, p. 112-113. Disponível em: < https://revista.enap.gov.br/index.php/RSP/article/view/328>. Acesso em 04 jun. 2019.

MORAES, Alexandre de. Direito Constitucional, 33a. ed. rev. e atual. até a EC no 95, de 15 de dezembro de 2016 - São Paulo: Atlas, 2017.

MORAIS, Janaína Jacolina. Princípio da Eficiência na Administração Pública. Disponível em: <http://www.eduvaleavare.com.br/wp-content/uploads/2014/07/principio_eficiencia.pdf>. Acesso em 04 jun. 2019.

MOREIRA, Egon Bockmann.. Processo administrativo: Princípios Constitucionais e a Lei 9.784/1999. 2a Ed. Malheiros: São Paulo, 2000.

NEUBERGER, D.; MARIN, S. R.. Algumas contribuições de Amartya Sen aos conceitos de 'eficiência' e 'equidade'. In: IV Seminário de Ciências Sociais Aplicadas, 2014, Criciúma - SC. Anais do IV Seminário de Ciências Sociais Aplicadas, v. 04, 2014.

NIED, Paulo Sérgio. O conceito de eficiência econômica e a ruptura do contrato de sociedade. In: XXI Encontro Nacional do CONPEDI, 2012, Uberlândia. Anais do XXI Encontro Nacional do CONPEDI. Florianópolis: Fundação Boiteux, 2012.

NOVELINO, Marcelo. Direito Constitucional. São Paulo: Método, 2009, 3ạ ed.

OLIVEIRA, Gilson Batista. Uma discussão sobre o conceito de desenvolvimento. Revista da FAE, Curitiba, v. 1, p. 37-48, 2002. Disponível em: <https://revistafae.fae.edu/revistafae/article/view/477>. Acesso em 04 jun. 2019.

OLIVEIRA, Gustavo Henrique Justino. Direito ao desenvolvimento na constituição brasileira de 1988. Revista Eletrônica de Direito Administrativo e Econômico, Salvador, n. 16, nov./jan., 2009. p. 12. Disponível em <http://www.direitodoestado.com.br/artigo/gustavo-henriquejustino-de-oliveira/direito-ao-desenvolvimento-na-constituicao-brasileira-de-1988>. Acesso em 04 jun. 2019.

PALUDO, Augustinho Vicente. Administração Pública: teorias e questões. Rio de Janeiro: Elsevier, 2012. 
PEDRAJA, F.; SALINAS, J.. Es posible medir la eficiencia de los servicios públicos? ECONOMISTAS - COLEGIO DE MADRID, Madrid, n 105, p. 86-93, jul 2005.

REALE, Miguel. Filosofia do Direito. São Paulo: Saraiva, 19ạ edição, 2002.

ROUSSEAU, Jean-Jacques. Discurso sobre a origem e os fundamentos da desigualdade entre os homens. São Paulo: Martin Claret, 2005.

SANDEL, Michael J.. Justiça - o que é fazer a coisa certa. 6a Edição, Rio de Janeiro: Civilização Brasileira, 2012.

SÁNCHEZ, Isabel María García. La nueva gestión pública: evolución y tendencias. Presupuesto y Gasto Público 47/2007: 37-64. Secretaría General de Presupuestos y Gastos. Instituto de Estudios Fiscales. Universidad de Salamanca, p. 44. Disponível em: <https://dialnet.unirioja.es/servlet/articulo?codigo=2341565>. Acesso em 04 jun. 2019.

SANTOS DIAS, Maria das Graças dos. Direito e pós-modernidade. Revista Novos Estudos Jurídicos, v. 11, n. 1, 2006. Disponível em: <http://siaiweb06.univali.br/seer/index.php/nej/article/download/424/366>. Acesso em: 04 jun. 2019.

SANTOS, Elinaldo Leal et al. Desenvolvimento: Um Conceito Multidimensional. Desenvolvimento Regional em debate, Revista Eletrônica do Programa de Mestrado em Desenvolvimento Regional da Universidade do Contestado, v. 2, p. 44-61-61, 2012, p. 45-47. Disponível em: <http://recipp.ipp.pt/bitstream/10400.22/1858/1/ART_ElinaldoSantos_2012.pdf>. Acesso em 04 jun. 2019.

SEN, Amartya Kumar. Desenvolvimento como liberdade. 4ạ reimpressão, São Paulo: Companhia das Letras, 2010.

. Desenvolvimento como liberdade. São Paulo: Companhia das Letras, 1999.

. Economía del crecimiento. Trad. de Eduardo L. Suárez - México: Fondo de Cultura Económica, 1979.

. Sobre Ética e Economia. Companhia das Letras. 7ạ ed. São Paulo. 2008.

. WILLIANS, B.. Utilitarism and beyond. Cambridge University Press, 1982.

SILVA, José Afonso da. Curso de direito constitucional positivo, São Paulo: Malheiros, 2005.

SZTAJN, Raquel. Law and Economics. In: Zylbersztajn, Décio; Sztajn, Raquel. (Org.). Direito e economia: Análise Econômica do Direito e das Organizações, 6a edição, Rio de Janeiro: Campus, 2005.

TAVARES, André Ramos. Direito constitucional econômico. São Paulo: Método, 2003.

TABAK, Benjamin Miranda. A Análise Econômica do Direito: Proposições Legislativas e Políticas Públicas. Revista de Informação Legislativa, v. 52, 2015.

VASCONCELOS, M. A.; GARCIA, M. E.. Fundamentos de economia. São Paulo: Saraiva, 1998.

VIEGAS, Eduardo Coral. O desenvolvimento sustentável como sobreprincípio. In: Antônio Herman Benjamin; Eládio Lecey; Sílvia Cappelli. (Org.). Mudanças climáticas, biodiversidade e uso sustentável de energia. 1ed. São Paulo: Imprensa Oficial do Estado de São Paulo, v. 1, 2008. 
VILA, Humberto. Moralidade, razoabilidade e eficiência na atividade administrativa. Revista Eletrônica de Direito do Estado, n. 4, p. 1-25, out.-dez., 2005. Disponível em: <http://www.direitodoestado.com.br/artigo/humberto-avila/moralidade-razoabilidade-eeficiencia-na-atividade-administrativa>. Acesso em: 04 jun. 2019. 